\title{
47. MAGNETIC PROPERTIES OF BASALTS FROM HOLE 504B, DEEP SEA DRILLING PROJECT LEG 691
}

\author{
J. B. O'Donovan and W. O'Reilly, Department of Geophysics and Planetary Physics, \\ University of Newcastle upon Tyne, Newcastle upon Tyne, NE1 7RU, United Kingdom
}

\begin{abstract}
The NRM intensity, AF demagnetization characteristics, hysteresis parameters, initial susceptibility, and thermomagnetic characteristics of 18 basalt specimens from Deep Sea Drilling Project Hole 504B were determined. In six samples, the grain size was large enough to allow microprobe analysis.

We conclude (1) that the dominant magnetic mineral is titanomagnetite/titanomaghemite; (2) that, except for the upper few meters of the core where the grains are in the stable monodomain state, the grain size of the magnetic mineral lies in the pseudo-single-domain range $(<10 \mu \mathrm{m})$; (3) that maghemitization (i.e., low-temperature $\left(\$ 350^{\circ} \mathrm{C}\right)$ oxidation) has taken place.

We discuss possible geological histories.
\end{abstract}

\section{INTRODUCTION}

The magnetic properties of rocks can be used to determine the composition and microstructure of the magnetic mineral fraction, which, in turn, is related to the petrological history of the host rock. The present study of basalt samples from DSDP Hole 504B is aimed at identifying the magnetic minerals and seeking evidence especially for low-temperature, post-deuteric alteration.

\section{EXPERIMENTAL PROCEDURES AND TECHNIQUES}

The samples consisted of 18 (nominally $1 \times 1$ ", $2.54 \times 2.54 \mathrm{~cm}$ cylinder) specimens drilled from the core obtained at Hole 504B, Leg 69 , together with an equal number of slices and/or chips.

The intensity and direction (only inclination is reported here) of the NRM was measured on a Digico spinner magnetometer. The stability of the NRM was investigated by progressive demagnetization in an alternating field, using a Highmoor AF demagnetizer. The maximum field used was $300 \mathrm{Oe}$, and in general this was sufficient to reduce the intensity by at least $90 \%$. The weak field susceptibility was measured using an AC susceptibility bridge after demagnetization. Hysteresis loops were recorded with a vibrating sample magnetometer run at room temperature and up to a maximum field of approximately $11 \mathrm{kOe}$. After removal of the paramagnetic component (determined from the high-field linear section of the hysteresis curve, and possibly including a super-paramagnetic fraction), values of saturation magnetization $\left(M_{\mathrm{S}}\right)$, coercive force $\left(H_{\mathrm{C}}\right)$, and the ratio of saturation remanence $\left(M_{\mathrm{RS}}\right)$ to saturation magnetization were obtained for each of the specimens. The variation of saturation magnetization with temperature (i.e., thermomagnetic curves) was measured on a vertical Curie balance. The samples (obtained from the slices and chips) were sealed in evacuated quartz capsules. The samples were saturated in a field of $10 \mathrm{kOe}$ and heated $/$ cooled at a rate of $5^{\circ} \mathrm{C} / \mathrm{min}$; from these curves, the Curie temperatures $\left(T_{\mathrm{c}}\right)$ were obtained.

Finally, polished sections were prepared so that the grains of the magnetic minerals present could be analyzed for $\mathrm{Fe}, \mathrm{Ti}, \mathrm{Al}, \mathrm{Mn}, \mathrm{Mg}$, $\mathrm{Cr}$, and $\mathrm{Si}$, using a Geoscan electron microprobe. In many of the samples, the size of the majority of the grains was below the resolving power of the probe (a few micrometers).

\footnotetext{
${ }^{1}$ Cann, J. R., Langseth, M. G., Honnorez, J., Von Herzen, R. P., White, S. M., et al., Init. Repts. DSDP, 69: Washington (U.S. Govt. Printing Office).
}

\section{RESULTS}

The bulk of the data obtained for the 18 samples of Hole 504B is summarized and illustrated in Tables 1 through 4 and Figures 1 through 4.

\section{Natural Remanent Magnetization}

The intensity of NRM $\left(I_{\mathrm{NRM}}\right)$, as can be seen from Figure 1A and Table 1 (column 6), is high for Samples 355 and 361 , but then drops sharply within a meter by approximately an order of magnitude, after which the variation of intensity with depth becomes very erratic. This type of behavior is also mirrored by the other parameters to be described later with the possible exception of the ratio $M_{\mathrm{F}} / M_{\mathrm{I}}$ (defined in caption to Fig. 3; see also Fig. 4). Average values of the intensity are also shown in Table 1; two values are given, the smaller value not including the results for Samples 355 and 361 . The values obtained are typical of basement rocks (see, for example, Lowrie, 1973, 1977; Day et al., 1979).

The variation of $I_{\mathrm{NRM}}$ with increasing alternating field was almost identical for each sample, showing a smooth decrease of intensity as a function of field. Values of inclination before and after demagnetization are listed in columns 8 and 9 of Table 1 . For the majority of samples, the change of inclination is less than $5^{\circ}$, and occurs mainly during the first (i.e., $25 \mathrm{Oe}$ ) demagnetization step. The smallest variation occurs for those samples (e.g., 355, 361, 964, 1487) with the highest MDFs, which are listed in column 7 of Table 1 and plotted as a function of depth in Figure 1B. A majority of the samples have a MDF greater than 100 Oe. Very high values of MDF, as found by Day et al. (1979) (up to 800 Oe) and Johnson and Hall (1976) (up to $500 \mathrm{Oe}$ ), are absent from this suite of samples.

\section{Hysteresis and Susceptibility}

The results obtained from hysteresis loops are listed in Table 2. The coercive force, $H_{\mathrm{c}}$, which is plotted in 

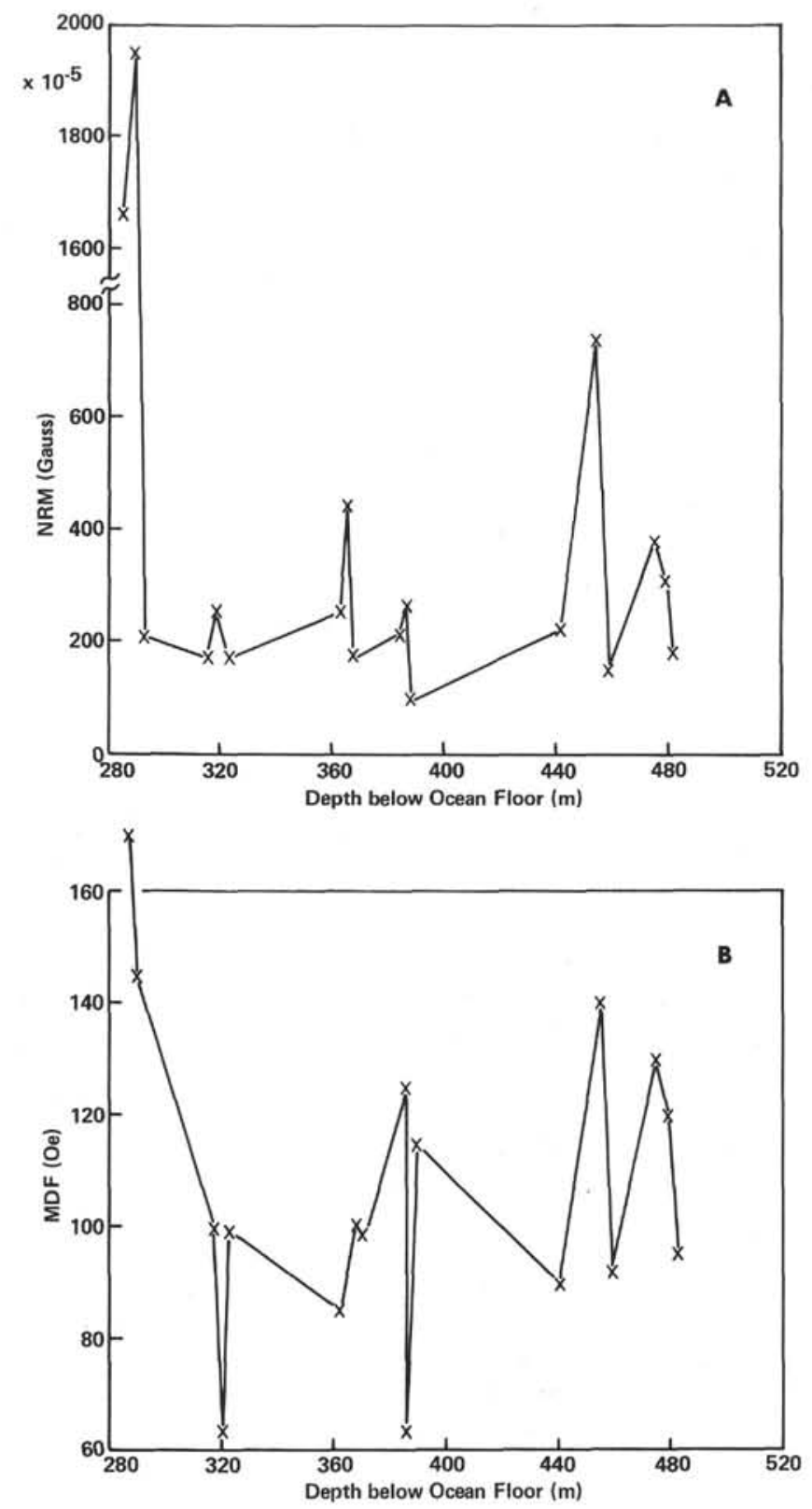

Figure 1A. Variation of intensity of natural remanent magnetization with depth below ocean floor. The intensity of the uppermost specimens is significantly higher than the bulk of the core (note the broken scale). (1 gauss $\left.=10^{3} \mathrm{~A} / \mathrm{m}\right)$. B. Variation of median destructive field of the NRM with depth. $(1 \mathrm{Oe}=80 \mathrm{~A} / \mathrm{m})$.

Figure 2A, drops steadily with increasing depth for the first 40 meters, but thereafter shows a rather more erratic variation, which also appears to be the inverse of that shown (Fig. 2B) by the weak field susceptibility $\left(\chi_{0}\right)$. This latter quantity is used to calculate the Koenigsberger ratio, $Q,\left(=I_{\mathrm{NRM} /} \chi_{0} H_{\mathrm{geo}}\right)$, which is listed in the last column of Table 1 . This varies in value from 1 to 74 , with averages of 12 or 5 (again eliminating the results obtained from Pieces 355 and 361). These values indicate that the remanent magnetization dominates the induced magnetization in these samples. The saturation magnetization, which depends on both concentration and composition of the magnetic phase, shows no systematic variation with depth (Fig. 3A).

\section{Thermomagnetic Curves}

A typical thermomagnetic curve is illustrated in Figure 4 and the results obtained from such curves are listed in Table 3. The type of behavior exemplified by Figure 4 has now become the hallmark of rocks obtained from the oceanic crust, showing the characteristic "inversion" of a metastable, cation-deficient spinel from an initial single phase to a multiphase product. These curves are described in terms of several Curie temperatures, which can be defined as follows: $T_{\mathrm{c}}^{1}=$ Curie temperature of original phase; $T_{\mathrm{c}}^{2}=$ Curie temperature of final stable phase; $T_{\mathrm{c}}^{3}=$ Curie temperature of phase formed by process of inversion. Also, there is the inversion temperature taken where the inversion process peaks on the thermomagnetic curve. The ratio $M_{\mathrm{F}} / M_{\mathrm{I}}$ (as defined in the caption to Fig. 3B) is plotted as a function of depth in Figure 3.

\section{Microprobe Analyses}

Electron-microprobe analyses of titanomagnetites from selected samples are listed in Table 4. The microprobe is unable to determine $\mathrm{Fe}^{3+}$ and $\mathrm{Fe}^{2+}$; thus, degrees of maghemitization cannot be determined. The cation concentrations for the analyzed grains therefore have been normalized to present a stoichiometric composition, i.e. $\mathrm{Fe}_{3-\mathrm{x}-\delta} \mathrm{M}_{\delta} \mathrm{Ti}_{x} \mathrm{O}_{4}$, where $\mathrm{M}=\mathrm{Al}, \mathrm{Mg}, \mathrm{Mn}$, $\mathrm{Cr}$, principally $\mathrm{Al}$ in the present suite. The $x$ value of titanomagnetite in basalt is typically 0.6 . Six specimens $(520,529,544,981,1371,1558)$ contained grains large enough to be analyzed and yielded $x$ values of 0.61 , $0.66,0.55,0.59,0.54$, and 0.55 respectively, with an average of 0.59 (Table 4 gives wt. \% element analyses). A magnetite analysis $\left(\mathrm{Fe}_{3} \mathrm{O}_{4}\right)$ was returned for two grains in Pieces 544 and 981 , but such grains must be rare, not being indicated by the thermomagnetic analysis, although the inversion process would tend to mask their presence. The analysis of a sulfide grain gave $\mathrm{Fe}_{0.42} \mathrm{~S}$, presumably non-magnetic pyrite.

\section{DISCUSSION}

\section{NRM Direction}

As the palaeomagnetic data will be discussed in detail elsewhere by Furuta and Levi (this volume), and because these authors also will be considering results from a much larger number of samples, it will be sufficient here to call attention to two points:

1) Although Hole 504B was drilled over a negative anomaly, the inclination data presented in Table 1 can be divided into nine positive values and nine negative values; and,

2) The value of the inclination for an axial geocentric dipole at the latitude of this site $\left(1^{\circ} 13.63^{\prime} \mathrm{N}\right)$ is $+2^{\circ}$, which appears to compare favorably with the arithmetic mean of the measurement inclination (i.e., $-3.7^{\circ}$ ), but it should be noted that the standard deviation of the mean is $\pm 39^{\circ}$. 
Table 1. Details of the studied Hole 504B samples, intensities and directions of natural remanent magnetization (NRM), initial magnetic susceptibility $\left(\chi_{i}\right)$, and Koenigsberger ratio $\left(I_{\mathrm{NRM}} /\right.$ $\left.\chi_{i} H_{\text {geo }}\right)$.

\begin{tabular}{|c|c|c|c|c|c|c|c|c|}
\hline $\begin{array}{c}\text { Sample } \\
\text { (interval in } \mathrm{cm} \text { ) }\end{array}$ & $\begin{array}{l}\text { Piece } \\
\text { No. }\end{array}$ & $\begin{array}{l}\text { Sub-bottom } \\
\text { Depth } \\
\text { (m) }\end{array}$ & $\begin{array}{l}I_{\mathrm{NRM}} \\
\times 10^{-5} \\
(\mathrm{G})\end{array}$ & $\begin{array}{l}\operatorname{MDF}_{(\mathrm{NRM})} \\
(\mathrm{Oe})\end{array}$ & $\begin{array}{c}\text { Inc. } 1 \\
\text { (degrees) }\end{array}$ & $\begin{array}{c}\text { Inc. } 2 \\
\text { (degrees) }\end{array}$ & $\begin{array}{c}x_{i} \\
\times 10^{-4} \\
\left(\mathrm{~cm}^{-3}\right)\end{array}$ & $\begin{array}{c}\begin{array}{c}\text { Koenigsberger } \\
\text { Ratio }\end{array} \\
\end{array}$ \\
\hline $504 \mathrm{~B}-4-5,105-107$ & 355 & 287.1 & 1664 & 170 & -0.2 & 0.7 & 7.1 & 60 \\
\hline $5-1,47-50$ & 361 & 290.0 & 1951 & 145 & -71.2 & -70.9 & 6.8 & 74 \\
\hline $5-2,10-13$ & 373 & 291.1 & 207 & 90 & -32.4 & -28.8 & 11.5 & 5 \\
\hline $8-1,12-14$ & 520 & 316.6 & 171 & 100 & -5.8 & -48.6 & 14.4 & 3 \\
\hline $8-2,60-63$ & 529 & 318.6 & 254 & 60 & 33.0 & 30.4 & 13.8 & 5 \\
\hline $8-3,143-145$ & 544 & 321.0 & 172 & 100 & 67,7 & 62.4 & 13.2 & 3 \\
\hline $13-2,90-95$ & 780 & 363.9 & 254 & 75 & -11.7 & 0.2 & 14.6 & 4 \\
\hline $13-3,51-54$ & 790 & 365.1 & 445 & 100 & -41.6 & -41.4 & 15.6 & 7 \\
\hline $13-4,65-68$ & 810 & 366.7 & 178 & 95 & 35.6 & 27.6 & 13.8 & 3 \\
\hline $16-1,70-73$ & 964 & 384.7 & 218 & 128 & -1.5 & -1.6 & 13.6 & 4 \\
\hline $16-2,81-83$ & 981 & 386.4 & 268 & 65 & -50.5 & -30.8 & 16.2 & 4 \\
\hline $16-3,25-27$ & 990 & 387.3 & 98 & 115 & 47.0 & 31.3 & 19.9 & 1 \\
\hline $24-2,123-126$ & 1371 & 441.7 & 226 & 90 & -0.4 & 1.7 & 16.4 & 4 \\
\hline $24-3,81-84$ & 1387 & 454.8 & 739 & 145 & -46.9 & -43.5 & 11.5 & 16 \\
\hline $25-2,9-13$ & 1421 & 458.6 & 149 & 92 & -44.2 & -39.7 & 17.4 & 2 \\
\hline $28-1,5-8$ & 1487 & 475.1 & 379 & 130 & 59.6 & 60.4 & 10.6 & 9 \\
\hline $28-3,45-48$ & 1527 & 478.5 & 311 & 120 & -28.7 & -44.6 & 15.2 & 5 \\
\hline $28-5,16-19$ & 1558 & 481.2 & 174 & 95 & 7.7 & 23.7 & 17.2 & 3 \\
\hline Average values & & & $\begin{array}{l}569.9 \pm 738 \\
265.2 \pm 154\end{array}$ & $107 \pm 29$ & $-4.7 \pm 41$ & $-3.7 \pm 39$ & $13.8 \pm 3.4$ & $\begin{array}{l}1.8 \pm 20.7 \\
4.9 \pm 3.5\end{array}$ \\
\hline $6-1,23-26$ & 6 & & 1445 & 68 & -47.4 & -86.1 & & 21 \\
\hline $6-1,123-126$ & 24 & & 909 & 68 & -11.4 & -2.1 & & 13 \\
\hline $13-1,22-25$ & 121 & & & & & & & \\
\hline $17-1,15-18$ & 284 & & & & & & & \\
\hline $17-2,33-36$ & 301 & & & & & & & \\
\hline $20-1,135-140$ & 423 & & & & & & & \\
\hline $20-4,33-37$ & 462 & & & & & & & \\
\hline
\end{tabular}

Table 2. Hysteresis parameters for Hole 504B basalts (1 gauss $\left.=10^{3} \mathrm{~A} / \mathrm{m} ; 1 \mathrm{Oe}=80 \mathrm{~A} / \mathrm{m}\right)$.

\begin{tabular}{|c|c|c|c|c|}
\hline $\begin{array}{c}\text { Piece } \\
\text { No. }\end{array}$ & $\begin{array}{l}M_{\mathrm{S}} \\
\text { (G) }\end{array}$ & $M_{\mathrm{RS}} / M_{\mathrm{S}}$ & & $\begin{array}{l}H_{\mathrm{C}} \\
(\mathrm{Oe})\end{array}$ \\
\hline 355 & 1.47 & 0.43 & 190 & \\
\hline 361 & 1.41 & 0.46 & 177 & \\
\hline 373 & 2.64 & 0.32 & 141 & $135 \pm 42$ \\
\hline 520 & 1.87 & 0.22 & 104 & \\
\hline 529 & 2.29 & 0.20 & 84 & \\
\hline 544 & 2.06 & 0.21 & 113 & \\
\hline 780 & 1.51 & 0.26 & 99 & \\
\hline 740 & 2.24 & 0.22 & 119 & \\
\hline 810 & 2.01 & 0.27 & 112 & $103 \pm 10$ \\
\hline 964 & 2.82 & 0.16 & 96 & \\
\hline 981 & 2.49 & 0.25 & 102 & \\
\hline 990 & 2.14 & 0.23 & 92 & \\
\hline 1371 & 1.76 & 0.21 & 103 & \\
\hline 1387 & 1.91 & 0.26 & 155 & \\
\hline 1421 & 2.20 & 0.21 & 108 & $107 \pm 41$ \\
\hline 1487 & 1.68 & 0.23 & 142 & \\
\hline 1527 & 1.98 & 0.28 & 146 & \\
\hline 1558 & 2.48 & 0.24 & 88 & \\
\hline Average values & $2.06 \pm 0.07$ & $0.26 \pm 0.07$ & \multicolumn{2}{|c|}{$121 \pm 31$} \\
\hline 6 & 1.11 & 0.26 & \multirow{2}{*}{\multicolumn{2}{|c|}{97}} \\
\hline 24 & 1.12 & 0.21 & & \\
\hline \multicolumn{5}{|l|}{121} \\
\hline \multicolumn{5}{|l|}{138} \\
\hline \multicolumn{5}{|l|}{284} \\
\hline \multicolumn{5}{|l|}{301} \\
\hline \multicolumn{5}{|l|}{423} \\
\hline 462 & & & & \\
\hline
\end{tabular}

\section{Particle Size}

The values of $M_{\mathrm{RS}} / M_{\mathrm{S}}$ given in Table 3 show a spread over the range 0.21 to 0.43 (mean $=0.26 \pm 0.07$ ), values which now have become regarded (Day, 1977) as an indication of the dominance of particles in the pseudo- single domain size range. This appears to be confirmed both by microscopy and by electron-microprobe studies, which suggest that the particle size is of the order of 10 $\mu \mathrm{m}$ or less. The magnetic properties suggest that the grain size is the smallest in the upper few meters (as indicated by Pieces 355 and 361). The Koenigsberger ratio and NRM intensity are an order of magnitude higher there than in the rest of the core. The coercive force, $\mathrm{M}_{\mathrm{RS}} / \mathrm{M}_{\mathrm{S}}$, and MDF have their highest values and initial susceptibility the lowest at the top of the core. It seems likely that the magnetic mineral is in the stable monodomain state.

\section{Maghemitization}

Recent work (O'Donovan, unpublished data; Rahman and Parry, 1978) has shown that stoichiometric titanomagnetite with $x \simeq 0.6$ would be expected to have a coercive force in the region of $500 \mathrm{Oe}$ for a particle size of 1 to $2 \mu \mathrm{m}$. However, it can be seen from Table 3 that the measured coercive forces for the basement samples are considerably less than 500 Oe.

It is known that the magnetic "hardness" of the titanomagnetites is strongly dependent on $\mathrm{Fe}^{2+}$ concentration. Any reduction in $\mathrm{Fe}^{2+}$ concentration will lead to a concomitant decrease in coercive force. Such a change can occur through the oxidation of titanomagnetite, involving the transformation of $\mathrm{Fe}^{2+}$ ions to $\mathrm{Fe}^{3+}$ ions. It is suggested therefore that the lower-than-expected coercive forces are a result of the chemical alteration of grains of titanomagnetite approximately $1 \mu \mathrm{m}$ (or less) in diameter, such a size being typical of rapidly cooled crystals. This possibility will now be discussed in more detail in the light of thermomagnetic curves.

It is now well established (see, for example, Prevot and Grommé, 1975; Hall and Ryall, 1977) that the stoichiometric titanomagnetite present in fresh oceanic ba- 


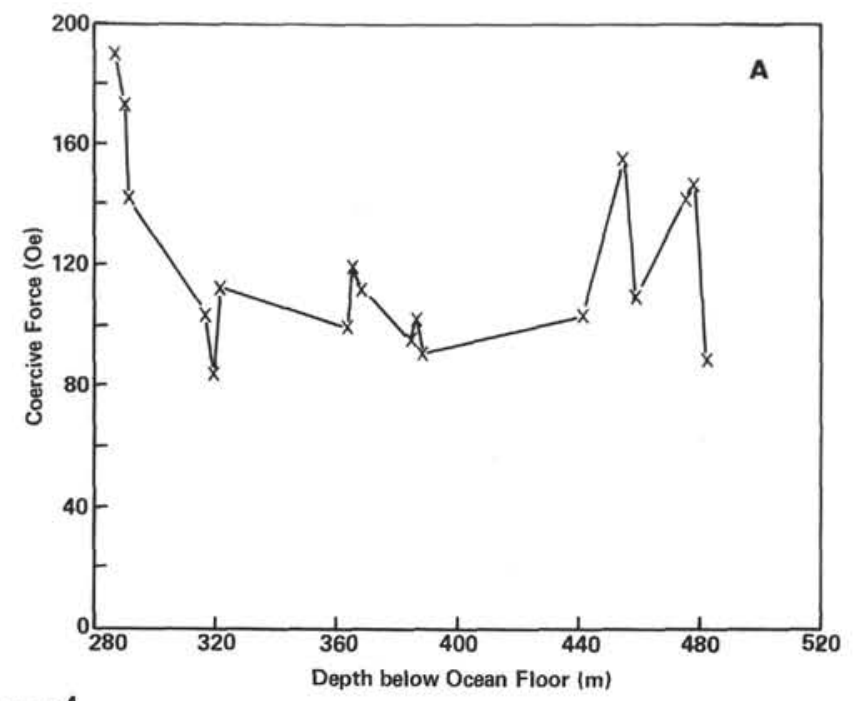

$\times 10^{-4}$

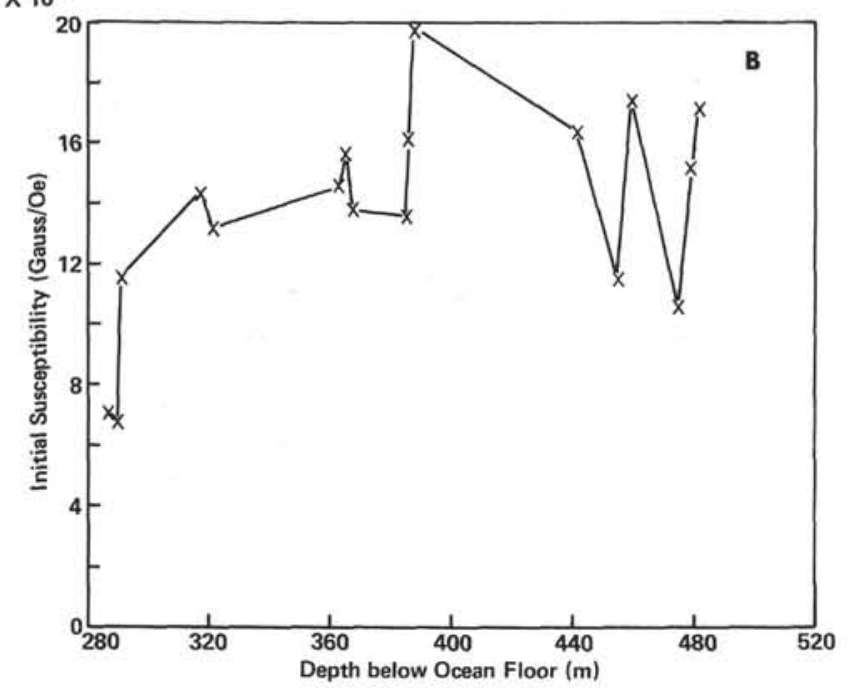

Figure 2. A. Variation of coercive force with depth $(1 \mathrm{Oe}=80 \mathrm{~A} / \mathrm{m})$. B. Variation of initial susceptibility with depth. (1 gauss $/ \mathrm{Oe}=4 \pi$ dimensionless MKS units of susceptibiity).

salts has a composition which corresponds to approximately $60 \%$ ulvospinel and $40 \%$ magnetite (i.e., $\left.\mathrm{Fe}_{2.4} \mathrm{Ti}_{0.6} \mathrm{O}_{4}\right)$, although it should be remembered that some "impurity" elements (e.g., $\mathrm{Al}, \mathrm{Mg}$ ) are also likely to be present. Hauptman (1974) has shown that titanomagnetite of the above-given composition has a Curie temperature of $150^{\circ} \mathrm{C}$, but it can be seen from Table 3 that the measured Curie temperatures exceed this value considerably. The reason for this is low-temperature oxidation of the original phase, causing the transformation $\mathrm{Fe}^{2+} \rightarrow \mathrm{Fe}^{3+}$, with a concomitant rise in Curie temperature.

Table 5 reproduces Curie temperature as a function of composition (Özdemir, 1979) for a range of synthetic materials. The oxidation parameter, $z$, is the "fraction of reaction," i.e., the fraction of the $\mathrm{Fe}^{2+}$ corresponding to stoichiometry, transformed to $\mathrm{Fe}^{3+}$.

The range of Curie temperatures measured for the present samples is 340 to $500^{\circ} \mathrm{C}$, with an average of $408 \pm 43^{\circ} \mathrm{C}$; using the above data it is possible to esti-
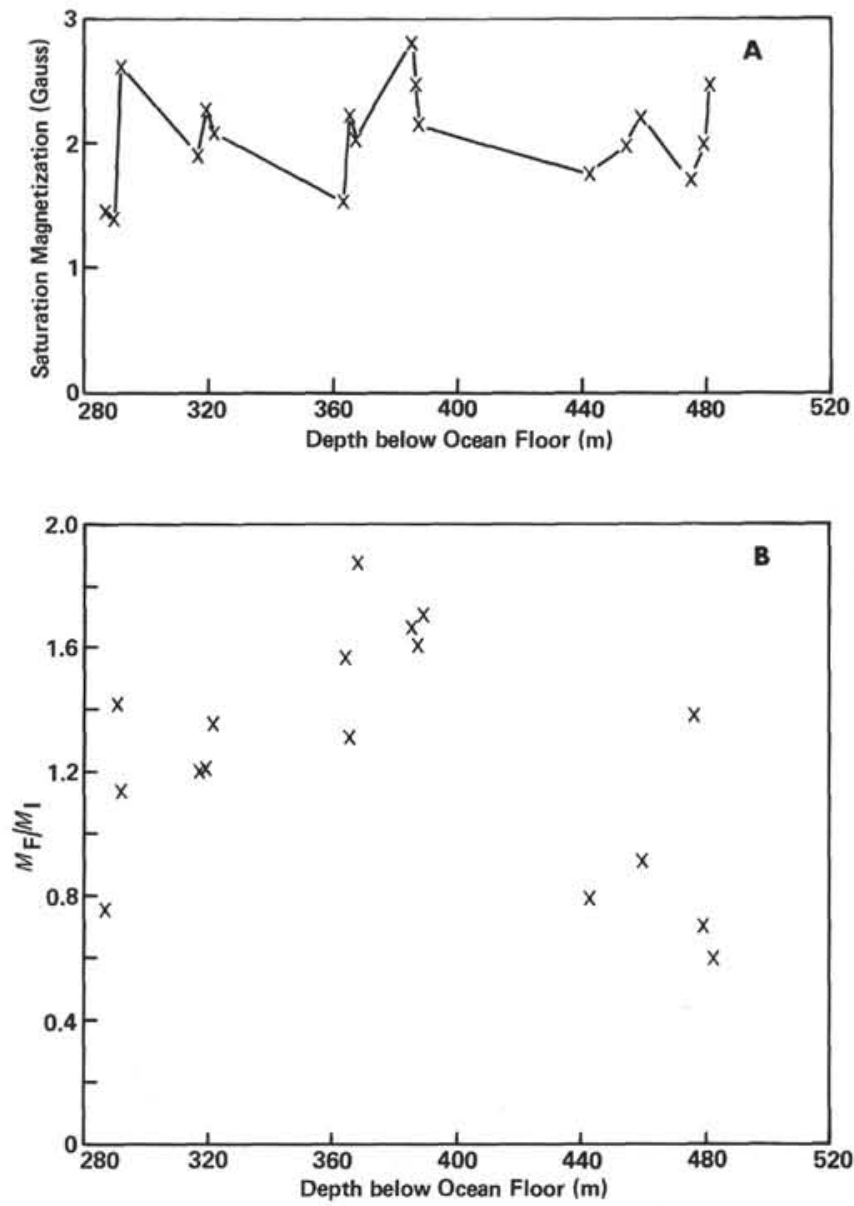

Figure 3. A. Variation of saturation magnetization of whole rock with depth $\left(1\right.$ gauss $\left.=10^{3} \mathrm{~A} / \mathrm{m}\right)$. B. Variation of $M_{\mathrm{F}} / M_{\mathrm{I}}$ (the ratio of induced magnetization in high field after and before inversion has taken place in the course of a thermomagnetic run) with depth.

mate the degree of oxidation, $z$, representing the fraction of $\mathrm{Fe}^{2+}$ converted to $\mathrm{Fe}^{3+}$ (Readman and O'Reilly, 1972). The results can be summarized as follows:

\begin{tabular}{ccc}
\hline $\begin{array}{c}\text { Curie } \\
\text { Temperature } \\
\text { Range }\end{array}$ & Estimated $z$ & $\begin{array}{c}\text { Piece } \\
\text { Numbers }\end{array}$ \\
\hline $340-370^{\circ} \mathrm{C}$ & $0.4-0.6$ & $\begin{array}{c}373,529,780, \\
1487,1558\end{array}$ \\
$390-420^{\circ} \mathrm{C}$ & $0.7-0.8$ & $\begin{array}{c}355,361,520, \\
544,1527\end{array}$ \\
$425-450^{\circ} \mathrm{C}$ & $0.9-1.0$ & $\begin{array}{r}790,810,981, \\
1371,1421\end{array}$ \\
\hline
\end{tabular}

It should be noted that, in the presence of impurities, even higher degrees of oxidation would be needed to explain the range of measured Curie temperatures.

It has also been found from studies on synthetics (O'Donovan, 1975; Ozdemir, 1979) that the ratio of saturation magnetization before heating $\left(M_{\mathrm{I}}\right)$ (Figure $3 \mathrm{~A})$, to saturation magnetization after heating $\left(M_{\mathrm{F}}\right)$ is a function of $z$, showing a marked increase with increasing $z$. If we use this parameter as a guideline, the samples can be split into three groups, indicated in Table 3 . 


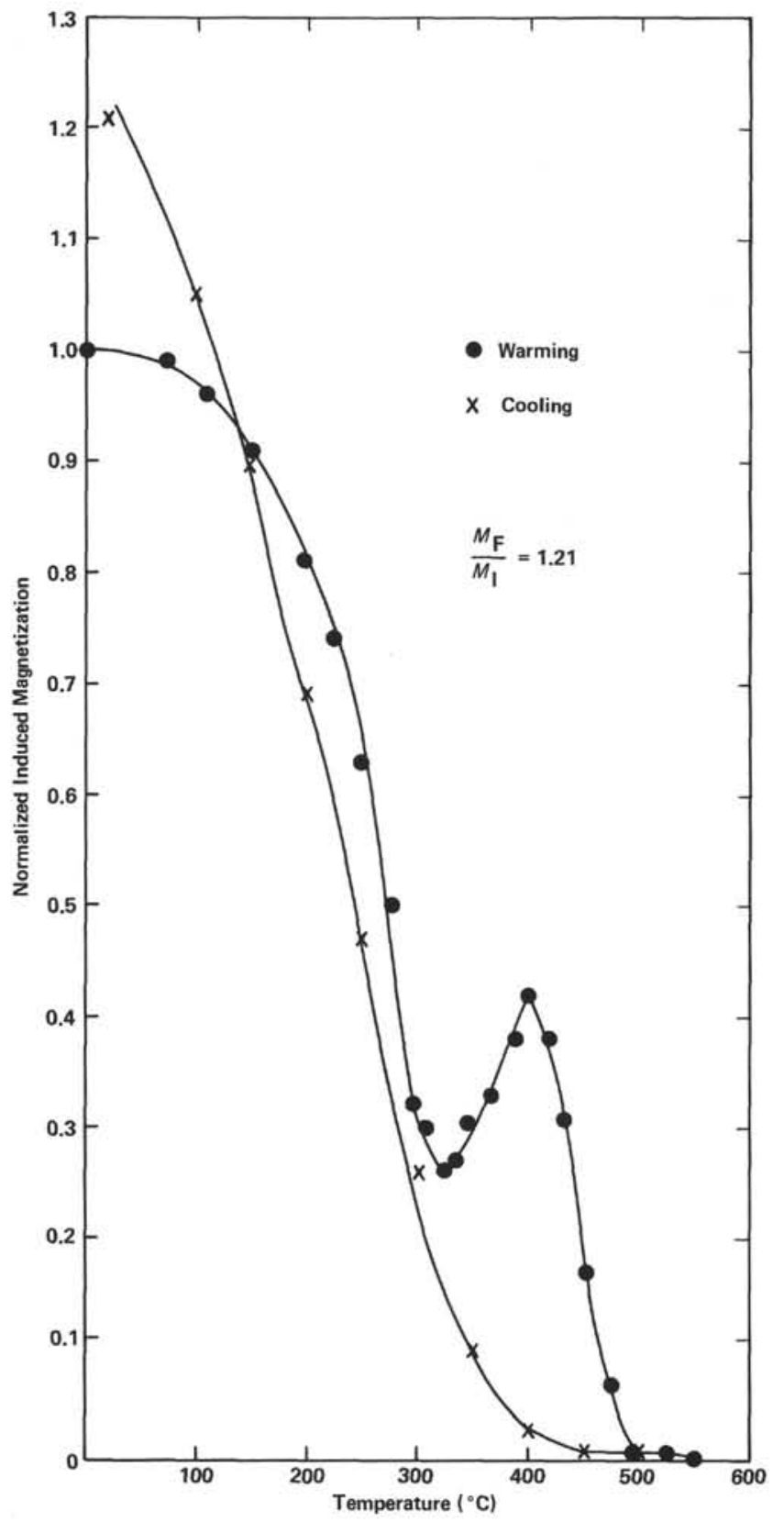

Figure 4. Variation of high-field induced magnetization of a basalt sample (Piece No. 529) encapsulated in vacuum, as a function of temperature. The sample "inverts" during the heating run, showing the characteristic titanomaghemite thermomagnetic curve.

Average Curie temperatures also have been calculated for these groupings, and the $T_{\mathrm{c}}$ values seem to show a similar trend, but not to the same degree.

Consequently, the middle group $\left(M_{\mathrm{F}} / M_{\mathrm{I}}=1.46\right)$ would consist of the highest oxidized samples, flanked by groups with lower degrees of oxidation. It may be noted that $M_{\mathrm{F}} / M_{\mathrm{I}}<1$ should indicate a high degree of oxidation, but that thermomagnetic runs on highly oxidized synthetics have not shown this.

Before discussing the origin of the variable maghemitization, we first must consider how the maghemitization took place. Oxidation can take place by either or
Table 3. Thermomagnetic data for Hole 504B basalt samples.

\begin{tabular}{|c|c|c|c|c|c|c|c|}
\hline $\begin{array}{l}\text { Piece } \\
\text { No. }\end{array}$ & $\begin{array}{c}T_{\mathrm{c}} \\
\left({ }^{\circ} \mathrm{C}\right)\end{array}$ & $\begin{array}{c}T_{\mathrm{C}}^{1} \\
\left({ }^{\circ} \mathrm{C}\right)\end{array}$ & $\begin{array}{c}T_{\mathrm{c}}^{2} \\
\left({ }^{\circ} \mathrm{C}\right)\end{array}$ & $\begin{array}{c}T_{\mathrm{c}}^{3} \\
\left({ }^{\circ} \mathrm{C}\right)\end{array}$ & $\begin{array}{c}\text { Inversion } \\
\text { Temperature } \\
\left({ }^{\circ} \mathrm{C}\right)\end{array}$ & $M_{\mathrm{F}} / M_{\mathrm{I}}$ & $\begin{array}{l}\text { Average } \\
M_{\mathrm{F}} / M_{\mathrm{I}}\end{array}$ \\
\hline 355 & \multirow{6}{*}{$383 \pm 31$} & $\int 420$ & 300 & 470 & 370 & 0.76 & \multirow{6}{*}{$1.18 \pm 0.23$} \\
\hline 361 & & 395 & 425 & 500 & 400 & 1.42 & \\
\hline 373 & & 350 & 350 & 460 & 375 & 1.14 & \\
\hline 520 & & 390 & 340 & 525 & 400 & 1.2 & \\
\hline 529 & & 340 & 350 & 485 & 400 & 1.21 & \\
\hline 544 & & 480 & 450 & 510 & 400 & 1.36 & \\
\hline 780 & \multirow{6}{*}{$420 \pm 28$} & $(370$ & 525 & 540 & 400 & 1.57 & \multirow{6}{*}{$1.46 \pm 0.57$} \\
\hline 790 & & 435 & 400 & 500 & 400 & 1.31 & \\
\hline 810 & & 430 & 460 & 550 & 410 & 1.89 & \\
\hline 964 & & -* & 450 & 520 & 380 & 1.67 & \\
\hline 981 & & 425 & 525 & 540 & 420 & 1.60 & \\
\hline 990 & & 1435 & 525 & 525 & 430 & 1.71 & \\
\hline 1371 & \multirow{5}{*}{$406 \pm 40$} & 450 & 280 & 505 & 400 & 0.78 & \multirow{5}{*}{$0.88 \pm 0.30$} \\
\hline 1421 & & 445 & 340 & 500 & 410 & 0.92 & \\
\hline 1487 & & 365 & 590 & 530 & 410 & 1.38 & \\
\hline 1527 & & 400 & 300 & 500 & 370 & 0.70 & \\
\hline 1558 & & 370 & 320 & 450 & 420 & 0.60 & \\
\hline \multicolumn{2}{|c|}{ Averages } & $408 \pm 43$ & $408 \pm 95$ & $506 \pm 28$ & $400 \pm 17$ & & \\
\hline
\end{tabular}

- Not possible to obtain estimate of Curie temperature.

Table 4. Element analyses obtained by electron microprobe for selected samples.

\begin{tabular}{rcccccccc}
\hline & \multicolumn{7}{c}{$\begin{array}{c}\text { Element Analysis } \\
\text { (wt.\%) }\end{array}$} \\
\cline { 2 - 9 } $\begin{array}{c}\text { Piece } \\
\text { No. }\end{array}$ & Fe & Ti & Al & Mn & Mg & Cr & Si & O \\
\hline 520 & 51.4 & 13.0 & 1.0 & 2.0 & 0.3 & 0.05 & 0.3 & 32.3 \\
529 & 52.4 & 13.8 & 1.1 & 0.7 & 0.5 & 0.06 & 0.36 & 81.1 \\
544 & 52.7 & 11.4 & 2.4 & 0.8 & 0.4 & 0.06 & 0.16 & 32.1 \\
981 & 53.5 & 11.9 & 1.0 & 0.7 & 0.2 & 0.04 & 0.22 & 32.4 \\
1371 & 52.9 & 11.0 & 0.7 & 1.3 & 0.55 & 0.03 & 0.7 & 32.7 \\
1558 & 54.7 & 11.5 & 1.2 & 0.4 & 0.4 & 0.04 & 0.81 & 30.9 \\
\hline
\end{tabular}

Table 5. Curie temperature as a function of degree of maghemitization for synthetic titanomagnetites (from Özdemir, 1979).

\begin{tabular}{ccc}
\hline & \multicolumn{2}{c}{ Curie Temperature $\left({ }^{\circ} \mathrm{C}\right)$} \\
$z$ & $\mathrm{Fe}_{2.4}{ }^{\mathrm{Ti}_{0}} 0.6 \mathrm{O}_{4}$ & $\mathrm{Fe}_{2.2}{ }^{\mathrm{Ti}} 0.6 \mathrm{Al}_{0.2} \mathrm{O}_{4}$ \\
\hline 0.2 & 300 & 155 \\
0.4 & 350 & 245 \\
0.6 & 375 & 290 \\
0.8 & 415 & 350 \\
1.0 & 450 & 410 \\
\hline
\end{tabular}

both of the mechanisms of "addition of oxygen" or "removal of metals." The source of oxygen in the present context may be magmatic gases or oxygen dissolved or combined in sea water or formation water. The metals, principally iron, may be leached out of the titanomagnetite grains by the sea water, possibly acquiring oxygen later and precipitating as ferric oxide. (The mechanism of maghemitization in submarine basalts is discussed by Petersen et al., 1979.)

The mechanism of removal of metals may produce high $\mathrm{Ti} / \mathrm{Fe}$ ratios if iron, principally, is leached out. The ratios in the present magnetic minerals are not unusually high. Extrusives may be maghemitized, at least superficially, during the explosive initial contact when the near-molten lava is surrounded and penetrated by superheated water. After quenching, extrusives may be 
affected by local heating near, for example, fumaroles. It is not clear whether the radial variation in degree of maghemitization in pillow basalts and systematic variation on a small (centimeter) scale can be accounted for by "initial maghemitization," or whether it is due to submarine weathering over times of the order of $10^{6}$ years. This question may be extended to submarine maghemitization at large. If initial maghemitization can effectively alter the titanomagnetites, each flow will be altered during emplacement and sealed by subsequent flows, which are altered in turn. Thus, the degree of maghemitization will not vary systematically on the intermediate scale $\left(\sim 10^{2} \mathrm{~m}\right)$ (i.e., with depth in the basement). If submarine maghemitization is the result of weathering over suitably long periods, the degree of alteration will depend on the contact with the weathering agent and time. The access of the weathering agent (sea water) to the titanomagnetite depends on the porosity of both the basement and any insulating sediment. Systematic variations in degree of maghemitization then might be expected on both the intermediate and large scale $\left(\sim 10^{3}-10^{6} \mathrm{~m}\right)$.

Hole 504B is in a region of submarine crust believed to have been rapidly covered with sediment which is essentially impermeable; hence, there is negligible exchange between the ocean and the sealed basement (see Langseth et al., this volume). The observed alteration in the magnetic minerals must have come about by initial maghemitization, by circulation of fluids in the hydrothermally sealed unit, or by both mechanisms. A systematic variation of degree of maghemitization over the sampled depth of the basement is not expected.

\section{CONCLUSIONS}

The basement basalts of Hole 504B have been altered by the low-temperature process of "maghemitization." This may be characteristic of a sealed hydrothermal system such as Hole 504B is believed to represent. However, unless alteration during and shortly after emplacement of the basalts can be discounted, this conclusion is only speculative. The grain size of the magnetic minerals is mainly in the pseudo-single-domain/monodomain range $(<10 \mu \mathrm{m})$, and the $\mathrm{Fe} / \mathrm{Ti}$ ratios are typical of titanomagnetites in basalts.

\section{ACKNOWLEDGMENTS}

We thank Mr. W. Rutherford, who sliced some of the specimens and made the NRM and AF demagnetization measurements, and Mr. W. T. Davison, who made the microprobe analyses. One of the authors (J. B. O'D.) is in receipt of a NERC research associateship. We thank Professor J. R. Cann, who suggested our involvement in the project, and finally the referees of this paper, Drs. P. Tucker and N. Petersen.

\section{REFERENCES}

Day, R., 1977. TRM and its variation with grain size: a review. In Dunlop, D. (Ed.), Advances in Earth and Planetary Sciences (Vol. 1). Origin of Thermo-remanent Magnetization: Tokyo (Japan Scientific Societies Press), pp. 1-33.

Day, R., Halgedahl, S., Steiner, M., Kobayashi, K., Furuta, T; Ishii, T., and Faller, A., 1979. Magnetic properties of basalts from DSDP Leg 49. In Luyendyk, B. P., Cann, J. R., et al., Init. Repts. DSDP, 49: Washington (U.S. Govt. Printing Office), 781-791.

Hall, J. M., and Ryall, P. J. C., 1977. Rock magnetism of basement rocks, Leg 37. In Aumento, F., Melson, W. G., et al., Init. Repts. DSDP, 37: Washington (U.S. Govt. Printing Office), 239-244.

Hauptman, Z., 1974. High temperature oxidation, range of non-stoichiometry and Curie point variation of cation deficient titanomag netite $\mathrm{Fe}_{2.4} \mathrm{Ti}_{0.6} \mathrm{O}_{4+\gamma}$. Geophys. J. Royal Astron. Soc., 38:29-47.

Johnson, H. P., and Hall, J. M., 1976. Magnetic properties of the oceanic crust: considerations from the results of DSDP Leg 34, 1976. J. Geophys. Res., 81:5281-5293.

Lowrie, W., 1973. Viscous remanent magnetization in oceanic basalts. Nature, 243:27-29.

1977. Intensity and direction of magnetization in oceanic basalts. J. Geol. Soc., 133:61-82.

O'Donovan, J. B., 1975. Studies on synthetic analogues of some carriers of the palaeomagnetic record [Ph.D. dissert.]. University of Newcastle upon Tyne, Great Britain.

Özdemir, O., 1979. An experimental study of thermoremanent magnetization acquired by synthetic monodomain titanomagnetites and titanomaghemites [Ph.D. dissert.]. University of Newcastle upon Tyne, Great Britain.

Petersen, N., Eisenach, P., and Bleil, U., 1979. Low temperature alteration of the magnetic minerals in ocean floor basalts. In Talwani, M., Harrison, C. G., and Hayes, D. E. (Eds.) Deep Drilling Results in the Atlantic Ocean: Ocean Crust: (Vol. 2) Washington (Am. Geophys. Union), 169-209.

Prevot, H., and Grommé, S., 1975. Intensity of magnetization of subaerial and submarine basalts and its possible change with time. Geophys. J. Royal Astron. Soc., 40:207-224.

Rahman, A. A., and Parry, L. G., 1978. Titanomagnetites prepared at different oxidation conditions: hysteresis properties. Phys. Earth Planet. Inter., 16:232-239.

Readman, P. W., and O'Reilly, W., 1972. Magnetic properties of oxidized (cation deficient) titanomagnetites $(\mathrm{Fe}, \mathrm{Ti}, \square)_{3} \mathrm{O}_{4}$. J. Geomagnet. Geoelec., 24:69-90. 